\title{
PUBLIC MOOD OF THE KUIBYSHEV REGION RESIDENTS IN 1990-1991 IN THE CONTEXT OF THE SOCIAL HISTORY OF RUSSIA
}

(C) 2018

\author{
Zakharchenko Alexey Vladimirovich, doctor of historical sciences, \\ head of History, International Law and Foreign Regions Studies Department \\ Kirdyashev Maksim Sergeevich, student of Law Faculty \\ Pankeeva Ksenia Viktorovna, student of Law Faculty \\ Samara Branch of Moscow City Pedagogical University (Samara, Russian Federation)
}

\begin{abstract}
This paper deals with 1990-1991 as a turning point, which marked the collapse of the policy of «perestroika», the communist institutions of power became a relic of the past, metamorphoses took place in the social structure of the Soviet society. The focus of «everyday life history» is the reality in the interpretation of its immediate participants, who were witnesses of the events of those years. Such events can relate to different spheres of life, and participants in these events can be people of different social strata. Newspapers and magazines are considered to be an irreplaceable source of information for studying the relationship between government and society in this chronological period. Letters and appeals of citizens from the regional newspaper «Volzhskaya Kommuna» were taken into consideration. There were rubrics expressing public opinion about the dynamics of the «perestroika» policy. The emotional reaction reflected in the letters is of great interest. The sources clearly record the main tendencies and stages of the public mood that prevailed in that period, thereby transfer the political apathy that spread in the society. The information received from the sources makes a definite contribution to the study of the «everyday life history» and can serve as a basis for research and reveal new aspects in social history.

Keywords: social history; everyday life history; perestroika; power and society; letters to power; macrohistory; microhistory; Kuibyshev; USSR; CPSU; Volzhskaya Kommuna; political science; sociology; economics; ideology; socialist society; nineties.
\end{abstract}

\section{«ДРУЖНО ЖИВЕМ, БЕШБАРМАК НАУЧИЛИСЬ ВАРИТЬ...»: К ВОПРОСУ О ТИПОЛОГИЧЕСКИХ МОДЕЛЯХ МЕЖЭТНИЧЕСКИХ ВЗАИМОДЕЙСТВИЙ В САМАРСКОМ ЗАВОЛЖЬЕ}

(C) 2018

\author{
Ягафова Екатерина Андреевна, доктор исторических наук, профессор, \\ заведующий кафедрой философии, истории и теории мировой культуры \\ Демидов Александр Николаевич, кандидат философских наук, \\ доцент кафедры философии, истории и теории мировой культуры \\ Самарский государственный социально-педагогический университет (2. Самара, Российская Федераџия)
}

Аннотация. В статье представлен опыт изучения межэтнических взаимодействий в Самарском Заволжье на примере с. Белозерки Красноярского района Самарской области. Теоретико-методологические подходы определялись концепцией «этнических границ», учитывающей дифференциальные признаки в культурных кодах контактирующих групп, а также различные факторы (исторический, социальный, демографический, экологический и другие), влияющие на формирование картины межэтнических отношений. Исследование преследовало цель - выявить механизм взаимодействия этнических групп, исторически проживающих в селении, в ситуациях межэтнических контактов (в том числе с мигрантскими сообществами), факторы, определяющие формирование и поддержание этнокультурной идентичности групп и существующих между ними этнических границ; определить характер взаимной социокультурной адаптации групп. В ходе исследования проведен анализ ситуации межэтнического взаимодействия в языковой, социально-экономической и этнокультурной сферах с учетом исторического фактора, дана характеристика этнических дихотомий (маркеров этничности) в основном на примере численно преобладающих групп русских, чувашей и мордвы. Результаты исследования показали наличие «этнических границ», обусловленных историей заселения с. Белозерки, культурной спецификой, особенностями языкового поведения и этнической идентификации, характером социально-экономических контактов групп и определивших смену различных моделей межэтнического взаимодействия в течение полувековой истории и их разнообразие в настоящее время. Факторами, поддерживающими групповую идентичность мордвы и чувашей, являются язык, функционирующий в семейно-бытовой сфере, внутриэтнические контакты в повседневной, но чаще в празднично-обрядовой сфере. Исследование основано на архивных, опубликованных источниках и полевых материалах авторов (2018 г.).

Ключевые слова: межэтнические отношения; этнические границы; Самарское Заволжье; русские; чуваши; мордва; этнические группы; этническая культура; этничность; этническая идентификация; изоляция; интеграция; ассимиляция; мигранты; социокультурная адаптация; переселения; Белозерки; Самарская область.

Постановка проблемы

Традиционно в рамках кросс-культурных исследований изучаются вопросы сходства и различий между культурами, исторических взаимосвязей народов, генезиса отдельных элементов культуры и др., но практически не уделяется внимания характе- 
Ягафова Е.А., Демидов А.Н

ру взаимодействия контактирующих этнических групп, эмпирической характеристике пролегающих между ними «этнических границ», раскрывающей механизм взаимоотношений этих групп. Такой подход особенно актуален при изучении полиэтничных районов, в которых взаимодействуют одновременно несколько этнических групп, а границы контактов проходят через территориально-поселенческие образования (города, селения) и социальные структуры (например, сельское общество, семья), создавая сложный механизм самоидентификации индивидов.

Самарская область - многонациональный и поликонфессиональный регион. По данным переписи 2010 г., в области проживают представители более 150 этнических групп и 20 конфессий. Современный этнический облик региона сложился в основном в XVII - первой половине XIX века в ходе активных миграций чувашей, татар, мордвы и русских - этнических групп, составляющих сегодня в нем численное большинство. Однако миграционные процессы XIX-XX вв., в которых участвовали украинцы, немцы, цыгане, евреи, греки, армяне и др., а также переселения выходцев из государств Закавказья, Средней Азии, республик Северного Кавказа в конце XX начале XXI в. существенно изменили этнический состав населения области. С учетом последнего исследовательский интерес представляет как исторический опыт межэтнических взаимодействий, сложившийся в ходе многовекового совместного освоения народами Самарского Заволжья, и современная этнокультурная ситуация в среде старожильческого населения, так и вопрос о форме, характере, интенсивности контактов этнических групп, исторически проживающих на территории Самарского края, с мигрантскими сообществами.

\section{История и методология вопроса, иель и задачи исследования}

Теоретико-методологические вопросы темы, в частности типология межкультурных взаимодействий, разрабатывались в работах В.П. Бранского [1], Н.К. Иконниковой [2] и др. Вопросы межэтнических отношений активно рассматривались в отечественной этнологии в последней четверти ХХ - начале XXI в. в трудах С.А. Арутюнова [3], Ю.В. Бромлея [4], В.И. Козлова [5], в рамках этносоциологического направления в работах Ю.В. Арутюняна [6], М.Н. Губогло [7], Л.М. Дробижевой [8], А.А. Сусоколова [9] и др.), в контексте проблем этничности и этнической идентичности - в работах В.А. Тишкова [10], А.Д. Коростелева [11] и др.

Проблема межкультурного взаимодействия в Урало-Поволжье представлена в работах исследователей второй половины XIX - первой половины ХХ в. (И.Н. Смирнов [12; 13], Н.В. Никольский [14] и др.). Исторический опыт и современные этнокультурные контакты населения региона рассматривались известными учеными во второй половине XX в.: Р.Г. Кузеевым [15], В.В. Пименовым [16; 17], К.И. Козловой [18], Т.С. Гузенковой [19]). В их трудах Волго-Уральский регион представлен как сплошное «поле» этнокультурных взаимодействий, наиболее ярко проявляющихся в контактных зонах, но актуальных в социальном взаимодействии на разных его уровнях (сельское поселение, семья и т.д.). Эти идеи были взяты на вооружение и получили развитие в ходе реализации проекта РГНФ № 06-01-00204a «Этнически смешанные селения в Урало-Поволжском регионе: историко-этнологическое исследование» (рук. А.Д. Коростелев) в 2006-2008 гг. В публикациях, появившихся по его результатам - статьях, двух сборниках статей (А.Д. Коростелев [20-23], Е.В. Попова [23; 24], Е.С. Данилко [23; 25], Р.Р. Садиков [23; 26], Т.Л. Молотова [23; 27], Е.А. Ягафова [23; 28-30]), внимание обращается на локальные контакты этнических групп в смешанных селениях; это аспект исследования актуален и в рамках настоящей статьи.

Теоретико-методологические подходы к изучению проблемы межэтнических отношений с позиции определения этнических границ контактирующих групп были обоснованы норвежским ученым Ф. Бартом [31]. Принципиально важное методологическое значение для изучения этнических границ в полиэтнических системах имеют такие тенденции, как изменчивость культурных признаков и формирование сходства кодов и ценностей в ситуации межэтнического взаимодействия, зависимость межэтнического взаимодействия от различий между ценностными ориентациями групп [31, с. 16-18, 21]. Последние являются одним из основных условий существования таких систем, поскольку разделяются членами этнической группы, обеспечивая ее стабильность, но одновременно выступают причиной запретов на смешение контактирующих групп. Вместе с тем для сохранения устойчивости полиэтничного сообщества эти различия должны взаимно дополнять друг друга. На характер взаимной адаптации этнических групп влияют также экологический и демографический факторы и связанные с ними производственный (экономический), социальный и политический параметры межэтнический отношений [31, с. 22-41]. В рамках данного исследования основное внимание будет уделено эмпирической характеристике этнических границ - выявлению дифференциальных признаков контактирующих этнических групп на примере локусов - контактных зон - в сельской местности Самарской области, в частности на примере с. Белозерки Красноярского района.

Цель исследования - выявление механизмов взаимодействия этнических групп, исторически проживающих на территории современной Самарской области (на примере с. Белозерки Красноярского района) в ситуациях межэтнических контактов (в том числе с мигрантскими сообществами), факторов, определяющих формирование и поддержание этнокультурной идентичности групп и существующих между ними «этнических границ», определение характера взаимной социокультурной адаптации разных этнических групп, выявление механизмов конструирования и поддержания групповых границ в сельском сообществе. Задачи - анализ ситуации межэтнического взаимодействия в языковой, социально-экономической и этнокультурной сферах; характеристика этнических дихотомий (маркеров этничности), определяющих этнические границы контактирующих групп; характеристика историко-культурных факторов межэтнических контактов.

Исследование опирается на архивные, опубликованные источники, а также полевые материалы авторов, собранные в с. Белозерки в сентябре 2018 г. с 
Ягафова Е.А., Демидов А.Н.

использованием качественных методов (глубинные полуформализованные интервью (13 человек), наблюдение, фото- и видеофиксация) [32; 33].

\section{Анализ данных}

Село Белозерки (Белозерка, Белоозеро; историческое название - Старая Дворянка (Дворяновка, Стародворяновка)) было основано в середине XIX в. русскими государственными крестьянами, потомками пахотных солдат, переведенными из окрестных селений Самарского и Ставропольского уездов: из Новой Бинарадки (16 семей), Нижней Орлянки (13), Раковки (8), Хорошенького (8), Бобровки (4), Спиридоновки (2), Красного Яра (4), Кривой Луки (1), Колывана (1) [34]. В свою очередь, на территорию Са- марского края пахотные солдаты переселились в середине XVIII века из Симбирского уезда, где они проходили службу на укрепленных линиях [35]. Впервые селение официально значится в материалах $\mathrm{X}$ ревизии (1857 г.).

В середине XIX в. в д. Белозерка (Старая Дворянская) проживал 631 чел. (таблица 1) [36, с. 7]. В течение последующих десятилетий численность населения динамично увеличивалась и достигла в 1889 г. 816 чел. (122 двора) [37, с. 23], в 1900 г. - 922 чел. (153 двора) [38, с. 43], в 1910 г. - 859 чел. (179 дворов) [39, с. 41], в 1931 г. - 1265 чел. (224 двора) [40, с. 83]. До революции в селе имелась церковь, церковноприходская школа, 2 ветряные мельницы [39, с. 41].

Таблица 1 - Численность и этнический состав с. Белозерки в середине XIX - начале XXI в.

\begin{tabular}{|c|c|c|c|c|c|}
\hline Год & Число дворов & Всего, чел. & Мужчин & Женщин & Этническая и сословная принадлежность \\
\hline 1859 & 98 & 631 & 296 & 335 & русские, государственные \\
\hline 1889 & 122 & 816 & 286 & 530 & русские, казенные \\
\hline 1900 & 153 & 922 & 466 & 456 & бывшие государственные русские православные \\
\hline 1910 & 179 & 859 & 433 & 426 & бывшие государственные русские православные \\
\hline 1928 & 140 & 812 & 381 & 431 & русские \\
\hline 1931 & 224 & 1265 & \multirow{5}{*}{\multicolumn{2}{|c|}{ нет данных }} & русские \\
\hline 1986 & нет данных & 996 & & & русские \\
\hline 2002 & нет данных & 1346 & & & русские (67\%) около 900 \\
\hline 2010 & нет данных & 1440 & & & нет данных \\
\hline 2016 & нет данных & 1624 & & & русские $(80 \%)$ \\
\hline
\end{tabular}

Во второй половине XX в. наблюдается снижение численности и изменение этнического состава населения Белозерок, хотя, по данным официальной статистики (1986 г.), оно продолжало считаться русским - 996 чел. [41, с. 50]. По данным переписи 2002 г., русские составляли 67\% населения (примерно 900 чел. из 1346 чел. общей численности) [42]. В настоящее время русские также преобладают, однако пятая часть (около 20\%) жителей представлена другими этническими группами: чувашами (144 чел.), мордвой (73), казахами (37), армянами (32), татарами (27), немцами (5), украинцами (5), а также узбеками, таджиками, белорусами, азербайджанцами [32]. При этом общая численность населения в последние два столетия уверенно растет и составила в 2010 г. 1440 чел. [43, с. 70], в 2016 г. - 1624 чел. [32].

Смена этнического состава произошла в начале 1970-х гг., когда по приглашению руководства местного совхоза им. Дзержинского для работы на животноводческих объектах в Белозерки переехали десятки семей чувашей и мордвы из северных районов области: Исаклинского, Клявлинского, Кошкинского, Челно-Вершинского, Шенталинского; переселялись и из соседних сел Красноярского района (Шилан, Новосемейкино, Старая Бинарадка) [32; 33]. Им предоставлялось жилье, высокооплачиваемая работа, что привлекало, в первую очередь, молодые семьи. Из интервью с Н.П. Беловой, уроженкой с. Каменка Шенталинского района: «Mbl поженились в 1978 г. Здесь в Белозерках уже жили тетка и младшая сестра. Совхоз был богатылм, дома вылделяли. Нам квартиру выделили. Муж был в почете, получше квартиру дали, потом коттедж» [32].

Приток в русское село нерусского населения из районов их компактного проживания, часто из крупных моноэтничных селений с многовековой истори272 ей, таких как с. Большое Микушкино Исаклинского района или с. Каменка Шенталинского района (оба чувашских села возникли в середине XVIII в.), со сложившимися этнокультурными традициями и формами социального взаимодействия определил характер межэтнических контактов на два последующих десятилетия (1970-1990-е гг.). Переселенцы, как правило, не имея опыта межэтнических контактов, стремились на новом месте выстраивать круг общения в привычной этнической среде. Сплоченность и взаимопомощь переселенцев помогала им обживаться на новом месте: «Когда приехали, чуваши помогали друг другу, за детьми смотрели. Чуваши вместе сажали картошку, дружно... молоко бесплатно давали»; «Mы здесь как одна семья жили. Все вместе. Пӗр семье пек пурӑннӑ. Пецрле пустарӑн$c a »$. Групповая солидарность чувашей контрастировала со взаимной враждой двух частей местного сообщества русских: «курских» и «бинарадских», проживавших в разных концах селения [32].

Активным межэтническим контактам препятствовали и различия в нормах социального поведения, проявлявшиеся, например, в вопросе благоустройства селения и личных подворий («Когда прuехали, село было некрасивым. Навоз перед домом лежал, стог сена перед домом. Разве у нас (чувашей - Е.Я.) такое увидишь?» [32]; «Грязь, колодизы были, колонок, дорог не было, по колено грязь» [33]). Местные жители, по словам чувашей, отличались нередко асоциальным поведением («Многие были наркоманами, тюремщиками. Если не был в тюрьме, плохой человек для них») [32].

Первую волну переселенцев местные жители встретили неприязненно, демонстрируя крайне негативные формы этнических стереотипов: «Когда $\mathrm{Mbl}$ приехали, нам говорили местные русские: «Понаеха- 
ли тут»... Нас обзывали: «Приехали трахомные чуваши...Немытые чуваши» [32]. Это стало еще одной причиной ограниченных контактов местного русского населения с мордвой и чувашами. В целом, взаимная неприязнь старожильческого населения и переселенцев, с одной стороны, и возможность внутригрупповой консолидации каждой из этнических групп, с другой стороны, обусловили формирование межэтнических отношений по типу взаимной изоляции.

В 1970-1980-х гг. село активно застраивалось, при этом возводились не только производственные помещения и жилые многоквартирные дома и коттеджи, но и объекты соцкультбыта: в 1970 г. - здание дирекции совхоза, магазин, в 1975 году - новое здание школы на 150 мест, в 1976 году - детсад, в 1985 - Дом культуры. Создавались благоприятные условия для социокультурного развития Белозерок, позитивно отражавшиеся на межэтнических отношениях жителей села. Тем не менее как в повседневной жизни, так и в праздники сохранялся приоритет внутриэтнических контактов. Так, в чувашской общине сформировался круг гостеваний, ориентированный на так называемые «престольные» православные праздники селений, выходцами из которых являлись переселенцы. Например, выходцы из с. Каменка Шенталинского района собирали гостей на праздник Козьмы и Демьяна (21 ноября), а выходцы из Аксаково того же района - на Николу зимнего (19 декабря); в круг гостеваний были включены почти все большие осенне-зимние праздники [32].

Таким образом, история Белозерок как этнически смешанного селения развивалась в последней четверти XX в., с одной стороны, на фоне взаимных негативных стереотипов переселенцев и местных жителей, противоречивых отношений среди старожильческого населения, обусловивших, в целом, изоляционистскую модель межэтнических взаимодействий. С другой стороны, формировавшиеся социальные (школа, Дом культуры, детский сад, магазины) и производственная (совхоз) площадки закладывали фундамент добрососедских отношений. Определенно положительное влияние оказало соседство в совхозных квартирах, в которых русские, чуваши, мордва расселялись дисперсно. Тем не менее ближний круг социального взаимодействия для каждой группы формировался преимущественно по этническому принципу.

С конца 1990-х и в последние десятилетия этнический состав с. Белозерки претерпел изменения в результате купли-продажи земельных участков с домом, в основном у русских жителей. Так в Белозерках появились татарские (5 семей), казахские (10), армянские (20), марийские (1), азербайджанские (1) семьи. Росла численность русского населения за счет также выкупавших землю жителей Самары; часть села под обиходным названием «Кулацкий поселок», заселена в основном русскими.

Изменение этнического состава населения вызвало структурные изменения в форме, типах межэтнических взаимодействий. По отношению ко всем «старожилам» «новопоселенцы» дистанцированы в силу позднего появления в селении. Однако их обособленность проявляется и в культурно-языковом Самарский научный вестник. 2018. Т. 7, № 4 (25) поведении: предпочтении общаться на родном языке («Tатары, армяне и казахи на своем разговаривают») и преимущественно в своей этнической среде, соблюдать свои обычаи. Из интервью с чувашами жителями с. Белозерки: «Они (армяне - Е.Я.) ведут себя высокомерно, не здороваются, отдельно живут. У них свои обычаи, свадьбы. Они свои обычаи ценят выше, будто говорят «у вас нет ничего». Все смотрят программы (ТВ - Е.Я.) на армянском языке». Впрочем, в отношениях с новопоселенцами для старожилов характерна, скорее, индивидуальная стратегия выстраивания контактов. Так, в интервью с чувашами же прозвучали и противоположные мнения: «У меня армяне в друзьях, и казахи тоже, в гости придешь, угостят. Уважаю их, у них преемственность в воспитании, дети помогают родителям», «Казахи бабушек уважают, внуки по гостям возят их», «Работала вместе с казахами, ходила к ним на Курбан-байрам, имянаречение, туй, на дни рождения», "Дружно живем, бешбармак научились варить». Таким образом, реальный характер добрососедских, в целом, контактов зависит от их длительности, интенсивности, индивидуального опыта общения («Все зависит от людей - с̧ынран килет»). О позитивных результатах свидетельствует хотя бы тот факт, что в меню чувашей есть «армянский суп», травы и специи армянской кухни, плов потаджикски. С другой стороны, этнические меньшинства также проявляют адаптивные склонности. Например, в общении с казахами это проявляется в смене антропонимов на русские имена: «Имена их произносим по-русски (Алсу - Светлана). Они не обижаются» [32].

Одним из определяющих факторов сохранения групповой идентичности и одновременно формирования «этнических границ» выступает этнокультурная специфика, проявляющаяся в особенностях материального быта, социальных нормах, религиозныхобрядовых традициях. В чувашской общине сохраняется празднование «престольных» праздников в соответствии с порядком гостеваний (см. выше), но при этом вместе с другими жителями Белозерок 15 января отмечается и праздник Св. Серафима Саровского, в честь которого в 2012 году было освящена местная православная церковь. Гостевание проводится и на пасхальной неделе мункун. При этом основной круг общения - чуваши, что обусловлено дружескими и семейно-родственными контактами. На фоне унификации материальной культуры (наиболее ярко проявляется в обустройстве жилища) пища и костюм сохраняют этнодифференцирующие признаки. Чуваши готовят блюда национальной кухни (пирог хуплу, колбасу шӑрттан, кисель мимёр, кецсел, пиво сӑра, самогон кумӑшка) в основном по праздникам. Но именно в рецептах приготовления блюд они различают «свои» и «чужие» рецепты: «Есть отличия чувашского хуплу от русского курника. В чувашском хуплу начинка выкладывается горкой последовательно слоями: рис, мясо, картофель. В курнике нет риса, только лук, мясо и картофель» [32]. Народный костюм в сценическом варианте обязательный элемент публичных мероприятий (см. ниже) для всех этнических групп, а в ряде случаев (свадьба) он выступает в качестве обрядовой одеж- 
ды, маркирующей этническую специфику события. Символическую, знаковую основу народный костюм сохранил, даже будучи вытесненным из повседневного быта. Неслучайно символом Белозерок как многонационального селения выступают куклы в нарядах русских, чувашей, мордвы, казахов, армян, любовно изготовленные местными жителями и выставленные в сельской библиотеке. В женском костюме чувашей в Белозерках (в одном из вариантов) воспроизведены черты закамско-заволжского комплек$\mathrm{ca}$, характерного для северо-восточных районов $\mathrm{Ca}$ марского Заволжья, что наряду с другими элементами культуры (обрядность, фольклор) и языка (диалект) свидетельствует о проявлении не только этнической, но и локальной идентичности группы. В целом, знание рецептов чувашских блюд и кухонь соседних народов, наряду с пониманием различий в языке, костюме, фольклоре и др., отчетливо свидетельствует о наличии «этнических границ» между чувашами и соседними народами. Степень их выраженности и устойчивости различается по отношению к разным этническим группам: в больше степени проявляется в контактах с новопоселенцами, в меньшей - с русскими и мордвой.

Преимущественно русскоязычное окружение влияет на языковое поведение чувашей и мордвы, в котором при сходстве общих характеристик (уровень владения языком) для обеих этнических групп наблюдаются и различия. Среднее и старшее поколение, выросшее в моноэтничных селениях, владеет родными (чувашским / эрзянским) языками в совершенстве (чуваши в т.ч. и письменным), но молодежь, родившаяся и выросшая в Белозерках, в лучшем случае понимает по-чувашски / по-эрзянски, а родным языком считает русский. При этом дети в чувашских семьях сохраняют этническое самосознание («Дети не владеют чувашским, но считают себя чувашами, поддерживают во всем», «Наши дети говорят: «Mbl - русские чуваши»») [32]. Способность детей понимать по-чувашски формировалась в мноэтничных чувашских семьях, в которых основным языком общения супругов был чувашский, хотя в общении с детьми родители переходили на русский язык. Наиболее благоприятные условия существовали в семьях, где участие в воспитании внуков принимали бабушки и дедушки, ежедневно общаясь с ними на чувашском языке.

В брачных контактах чувашей в последние десятилетия наблюдаются устойчивая ориентация на русских, другие варианты (таджик, крымская татарка, казах) встречаются единично. Дети в таких браках - русские, но общение с чувашскими бабушками и дедушками определенным образом влияет на внуков: «Дочь живет в Тольятти, замужем за русским, двое детей. Старший говорит: «Я хочу научиться по-чувашски»; "Сын женат на русской. Внук знает «Аван-и» (рус. «Здравствуйте»- Е.Я.)» [32].

В отличие от чувашей белозерская мордва была с самого начала больше ориентирована на русских и русский язык. Браки с русскими заключало уже первое поколение переселенцев в 1970-х гг.; в моноэтничных семьях основным языком общения супругов между собой и с детьми нередко был и остается русский язык. Из интервью с Т.В. Колесниковой, уро- женкой деревни Красная Елха Клявлинского района и А.Н. Кутузовой, уроженкой поселка Родина Шенталинского района: «Мы стараемся с мужем дома по-русски разговаривать... а дома у нас (в семье) два пацана, и мы с ними по-русски, а с мужем помордовски разговаривали только тогда, когда нам надо было посекретничать, чтобы дети не поняли»; «Я мордовка и муж мордвин, но мы в семье как-то мало разговариваем, только по секрету от детей. Дети языка не знают». Дети осваивают мордовский (эрзянский) язык в лучшем случае на уровне понимания, что сказывается и на их этнической идентификации: «...мой сын...конечно, скажет, что он русский». Среди мордвы были более выражены ассимиляционные тенденции, при этом выбор мордвой русской идентичности мог быть следствием как объективной ситуации (этническое меньшинство среди русских), так и осознанного решения («все хотели быть русскими»). Последнее могло противоречить приписываемой этничности (мордва), вызывая болезненные переживания по поводу своей этнической принадлежности: «B деревне соседка жила. Она даже не знала, что мордва, а когда паспорт получать, ей пишут национальность «мордовка», они чуть не выкинули паспорт». Тем не менее подъем национально-культурного движения среди народов России в последние три десятилетия позитивно сказался на этнической идентификации третьего поколения белозерской мордвы - поколении внуков, которые, не зная языка и не будучи приобщены к традиционной культуре народа, гордо заявляют: «Я - мордвин». Из интервью с Т.В. Колесниковой: «Внук ходил на борьбу и говорит: «У нас все национальности на борьбе: армянин, чеченеи и я-мордвин», прямо так и говорит: «Я мордвин». - Я думала, ты русский, а он говорит: «Нет, я-мордвин». - То есть дети у вас русские, а внуки мордва? - Да, да, так бывает» [33].

Консолидирующим началом для русских, мордвы и чувашей в Белозерках выступает религиозный фактор. Православная церковь, общие праздники, в т.ч. единый престольный праздник, формируют представление о конфессиональной общности, способствующее социальным контактам групп (браки, дружба). Полувековой срок совместного проживания, опыт производственных и социальных контактов создали предпосылки для изменений в русскомордовско-чувашских отношениях - сдвиг в стороны интеграции этнических групп в единое сельское сообщество с приоритетным русским языком общения и православной религией; в ряде случаев наблюдается ассимиляция (русификация) чувашей и мордвы.

Актуальным вопросом жизни сельского сообщества с учетом сложного этнического состава населения является сохранение мира и согласия между т.н. «старожильческим» населением и группами переселенцев последних десятилетий, принесших в Белозерки не только этнографическую специфику (в пище, языке и т.д.), но и иной образ жизни, другие поведенческие модели и экологическую культуру. Так, «старожилов» удивляет замкнутость, необщительность соседей. Появление азербайджанской семьи, занимающейся интенсивным животноводством в производственных масштабах (разводят крупный рогатый скот, коз, овец, птицу) на соседнем с церковью 
участке стало причиной недовольства со стороны местных жителей, высказанного во время экспедиции в 2018 г. Вместе с тем единые подходы и нормы природопользования - не менее значимый фактор добрососедских отношений, чем уважение к языку или религии другого народа.

На консолидацию многонационального населения Белозерок направлены массовые мероприятия, целенаправленно проводимые местной администрацией. Одно из наиболее крупных и значимых с символичным названием «Праздник дружбы, любви и согласия» состоялось 29 июня 2013 года в связи с празднованием 150-летия образования села (жители ошибочно отсчитывают историю села с 1863 года). Программа включала «День национальных культур» презентацию традиций наиболее многочисленных этнических общин: русской, чувашской, мордовской, казахской, армянской, татарской. Каждая из них представляла блюда национальной кухни, произведения декоративно-прикладного искусства, народные песни и танцы.

Фестиваль стимулировал интерес членов общины к своим этническим корням, способствовал развитию и уже существовавших традиций (например, кружка «Волшебная глина», в продукции которого появились изделия с этническими элементами в декоре), и новых направлений в самодеятельном творчестве. Так, возникли фольклорные группы - русская «Мирница», чувашская «Пилеш» («Рябина»), мордовская «Чевгель» («Калина») [32]. Коллективы сами формируют репертуар выступлений, включающий как популярные этнические мелодии и песни, так и распространенные в родных селениях чувашей и мордвы, по собственным эскизам шьют костюмы. Они активно гастролируют. «Чевгель», например, выступает в мордовских селениях Самарской области, а также в Ульяновской области и Мордовии, участвовал в съемках фильма о скульпторе С. Эрьзе. Участники самодеятельности привлекают к выступлениям своих детей и внуков, которые тем самым приобщаются к этническим традициям, учат языки [33].

Задачи публичной презентации этнокультурных традиций народов решают и этнические праздники. В июне 2018 г. в Белозерках прошел ХХІ Областной чувашский праздник «Акатуй», собравший чувашей и гостей из Самарской области и соседних регионов. Примечательно, что право принять «Акатуй» было предоставлено Красноярскому району благодаря активности белозерских чувашей, постоянно участвующих в региональных фестивалях и праздниках.

\section{Заключение}

Современная картина межэтнических взаимодействий в с. Белозерки Красноярского района Самарской области складывалась на протяжении полувека и может быть разделена на два этапа: 1) начало 1970 х гг. - конец 1990-х гг., когда сформировалась основа этнической структуры населения, представленная русскими, чувашами, мордвой; 2) конец 1990-х гг. до настоящего времени, связанный с притоком немногочисленных этнических групп «новопоселенцев» (казахов, армян, татар и др.), осложнившим процесс межэтнического общения в селе.

Взаимодействие этнических групп (русские, чуваши, мордва) на первом этапе осуществлялось в со- ответствии с изоляционистской моделью: контакты были ограничены преимущественно производственной (совхоз) и публичными площадками (объекты соцкультбыта), в то время как приоритетным кругом общения в приватном пространстве (включая семейно-родственные связи) для каждой из групп являлись члены своего этнического сообщества.

Изменение этнического состава населения на втором этапе вызвало структурные изменения в межэтнических отношениях в Белозерках. С одной стороны, это привело к определенной консолидации русских, чувашей, мордвы на основе конфессиональной общности, этнокультурной близости, а также опыта совместного проживания, что отразилось на характере брачных связей, особенностях этнической идентификации молодого поколения; в этом случае мы наблюдаем переход от изоляционистской модели к интегративной (а в некоторых случаях и ассимилятивной) в отношениях «старожильческого» населения. С другой стороны, вторжение в сельское сообщество иноэтнических традиций, существенно отличающихся от облика культуры поволжских народов (включая русских), обострило проблему «этнических границ» между т.н. «старожильческим» населением и «новопоселенцами», отношения между которыми представляют изоляционистскую модель межэтнических взаимодействий. Нарушают ее только разнообразные межэтнические контакты на индивидуальном уровне.

Факторами, поддерживающими групповую идентичность мордвы и чувашей, являются язык, функционирующий в семейно-бытовой сфере, внутриэтнические контакты в повседневной, но чаще в празднично-обрядовой сфере. Элементы этнической культуры (пища, костюм, фольклор), которые, безусловно, являются основой этнической идентичности и способом поддержания «этнических границ», в иноэтническом окружении приобрели также символический смысл и служат формами и способом ее презентации окружению. Публичное представление этнокультурных традиций, проведение массовых мероприятий с участием этнических групп направлено на их взаимную социокультурную адаптацию. Вместе с тем отсутствие общих экономических интересов и различные подходы к использованию природных ресурсов могут значительно осложнить характер межэтнических отношений в Белозерках.

\section{Список литературы:}

1. Бранский В.П. Теоретические основания социальной синергетики // Петербургская социология. 1997. № 1. C. 149-179.

2. Иконникова Н.К. Механизмы межкультурного восприятия // Социологические исследования. 1995. № 11. C. 26-34.

3. Арутюнов С.А. Народы и культуры. Развитие и взаимодействие. М.: Наука, 1989. 247 с.

4. Бромлей Ю.В. Очерки теории этноса. М.: Наука, 1983. 418 с.

5. Козлов В.И. Этнос, нация, национализм. Сущность и проблематика. М.: Старый сад, 1999. 341 с.

6. Арутюнян Ю.В. Социально-культурные аспекты развития и сближения наций в СССР (программа, методика и перспективы исследования) // Советская этнография. 1972. № 3. С. 3-19. 
7. Губогло М.Н. Идентификация идентичности: Этносоциологические очерки. М.: Наука, 2003. 764 с.

8. Дробижева Л.М. Социальные проблемы межнациональных отношений в постсоветской России. М.: Центр общечеловеческих ценностей, 2003. 376 с.

9. Сусоколов А.А. Межнациональные браки в СССР. М.: Мысль, 1987. 142 с.

10. Тишков В.А. Реквием по этносу: Исследования по социально-культурной антропологии. М.: Наука, 2003. 544 с.

11. Коростелев А.Д. Локальные особенности этнокультурных взаимодействий в Урало-Поволжском регионе // Русский язык в тюрко-славянских этнокультурных взаимодействиях: сб. ст. М., 2005. С. 54-62.

12. Смирнов И.Н. Вотяки. Историко-этнографический очерк // Известия Общества археологии, истории и этнографии. Казань, 1890. Т. VIII. Вып. 2. 308 с.

13. Смирнов И.Н. Мордва: историко-этнографический очерк. Саранск: НИИ гуманитарных наук при Правительстве Республики Мордовия, 2002. 296 с.

14. Никольский Н.В. Христианство среди чуваш Среднего Поволжья в XVI-XVIII веках. Исторический очерк // Известия Общества археологии, истории и этнографии. T. XXVIII. Вып. 1-3. Казань, 1912.

15. Кузеев Р.Г. Народы Среднего Поволжья и Южного Урала: Этногенетический взгляд на историю. М.: Наука, 1992. 347 с.

16. Пименов В.В. Удмурты: опыт компонентного анализа этноса. Л.: Наука, 1977. 262 с.

17. Пименов В.В. Урало-Поволжская историкоэтнографическая область // Проблемы типологии в этнографии. М.: Наука, 1979. С. 39-48.

18. Козлова К.И. Проблемы изучения контактных зон Среднего Поволжья // Вопросы этнографии Удмуртии. Ижевск, 1976. С. 39-48.

19. Гузенкова Т.С. Межэтнические контакты и этнокультурные процессы (по материалам о народах Урало-Поволжья) // Расы и народы. Вып. 13. М.: Наука, 1983. С. 99-113.

20. Мы и как удмурты, и как чуваши... Взаимная социально-культурная адаптация в этнически смешанных селениях Урало-Поволжья: сб. статей / под ред. А.Д. Коростелева. М.: РУДН, 2007. 198 с.

21. Опыт взаимодействия и взаимной адаптации в этнически смешанных селениях: сб. статей / под. ред. А.Д. Коростелева. М., 2009. 221 с.

22. Коростелев А.Д. Межэтнические браки в этнически смешанных селениях Приуралья и Поволжья (по материалам экспедиций 2006, 2007, 2008 гг.) // Этнографическое обозрение. 2010. № 6. С. 22-34.

23. Данилко Е.С., Коростелев А.Д., Молотова Т.Л., Попова Е.В., Садиков Р.Р., Ягафова Е.А. Опыт исследования взаимной социально-культурной адаптации в этнически смешанных селениях // Адаптация народов и культур к изменениям природной среды, социальным и техногенным трансформациям / отв. ред. А.П. Деревянко, А.Б. Куделин, В.А. Тишков. М.: Наука, 2010. С. 344-350.

24. Попова Е.В. Удмурты в этнически смешанных селениях Урало-Поволжья: опыт соседства // Этнографическое обозрение. 2010, № 6. С. 66-80.

25. Данилко Е.С. Татары в этнически смешанных поселениях Урало-Поволжья: особенности межкультурных взаимодействий // Этнографическое обозрение. 2010. № 6. С. 54-65.
26. Садиков Р.Р. Процессы межконфессионального взаимодействия в этнически смешанных селениях Урало-Поволжья: история и современные тенденции развития // Этнографическое обозрение. 2010. № 6. C. 9-22.

27. Молотова Т.Л. Религиозный фактор в сохранении идентичности восточных марийцев // Этнографическое обозрение. 2010. № 6. С. 81-92.

28. Ягафова Е.А. Чуваши в межкультурном пограничье Урало-Поволжья // Этнографическое обозрение. 2009. № 6. С. 120-133.

29. Ягафова Е.А. Чуваши в межэтническом взаимодействии в Закамье // Этнографическое обозрение. 2010. № 6. С. 35-53.

30. Ягафова Е.А. Этнокультурное взаимодействие в Урало-Поволжье // Проблемы этнокультурного взаимодействия в Урало-Поволжье. Самара: ПГСГА, 2013. C. 5-10.

31. Этнические группы и социальные границы. Социальная организация культурных различий / под. ред. Ф. Барта. М.: Новое издательство, 2006. 200 с.

32. Полевые материалы Е.А. Ягафовой. С. Белозерки Красноярского района Самарской области (информанты Белова Н.П., 1957 г.р., урож. с. Каменка Шенталинского района Куйбышевской области; Семенова 3.П., урож. д. Толчеречье Шенталинского района Куйбышевской области; Ефимова Л.Н., 1962 г.р., урож. д. Чепкас-Ильметьево Шемуршинского района Чувашской Республики; Хмелева Е.Ф., урож. с. Каменка Шенталинского р-на Куйбышевской области; Чеснокова Т.И., 1946 г.р., урож. с. Большое Микушкино Исаклинского района Куйбышевской области).

33. Полевые материалы А.Н. Демидова. С. Белозерки Красноярского района Самарской области (информанты Андриянова В.В., 1968 г.р., урож. с. Шилан Красноярского района Куйбышевской области, Воробьева О.Ф., 1974 г.р., урож. с. Новый Казбулат Клявлинского района Куйбышевской области, Карнецких Ю.В., 1975 г.р., урож. с. Раковка Красноярского района Куйбышевской области, Колесников П.Г., 1956 г.р., урож. с. Подгорный Дол Клявлинского района Куйбышевской области, Колесникова Т.В., 1957 г.р., урож. д. Красная Елха Клявлинского района, Кутукова А.Н. 1956 г.р. и Мокеева Н.П. 1955 г.р., урож. п. Родина Шенталинского района, Синяева Л.И. 1955 г.р., урож. с. Новый Казбулат Клявлинского района Куйбышевской области, урож. с. Новый Казбулат Клявлинского района Куйбышевской области, Чубукова О.Н., 1961 г.p., урож. с. Раковка Красноярского района Куйбышевской области).

34. Центральный государственный архив Самарской области. Ф. 150. Оп. 1. Д. 1573. Л. 752.

35. Российский государственный архив древних актов. Ф. 350. Оп. 2. Д. 3141. Л. 356-649; Д. 3142. Л. 12 об.-54; Д. 3154. Л. 295; Д. 3157. Л. 569; Д. 3160. Л. 26, 42-42 об., 519, 523; Д. 3164. Л. 602, 622-622; Д. 3165 . Л. 656, 677; Д. 3166. Л. 293-300; Д. 3158. Л. 273; Д. 3171 . Л. 287 об., 295.

36. Список населенных мест по сведениям 1859 года. Т. XXXVI. Самарская губерния. СПб.: Изд. Центр. Стат. комитетом Мин-ва внутр. дел, 1864. $134 \mathrm{c}$. 
37. Список населенных мест Самарской губернии по сведениям 1889 года. Самара: Изд. Сам. Губ. Стат. Комитета, 1890. 297 с.

38. Список населенных мест Самарской губернии, составленный в 1900 году секретарем Сам. Губ. Стат. Комитета И.А. Протопоповым. Изд. неофиц. 520 с.

39. Список населенных мест Самарской губернии. Самара: Губерн. типография, 1910. 425 с.

40. Список населенных пунктов Средне-Волжского края. Самара: Изд. Средневолжск. крайисполкома, 1931. $274 \mathrm{c}$

41. Справочник административно-территориального деления Куйбышевской области на 1 января 1986 года. Куйбышев: Куйбышев. кн. изд-во, 1986. 128 с.
42. Самарская область // Коряков Ю.Б. База данных «Этно-языковой состав населенных пунктов России»: http://lingvarium.org/russia/settlem-database.shtml.

43. Численность и размещение населения Самарской области по данным Всероссийской переписи 2010 года. Стат. сборник. Самара: Самарастат, 2012. $113 \mathrm{c}$.

Исследование выполнено при финансовой поддержке РФФИ и Самарской области в рамках научного проекта № 18-49-630002 «Этнические группы в межкультурном пограничье в Самарском Заволюжье: исторический опыт взаимодействия и современные процессы»"

\section{«WE LIVE IN PEACE AND FRIENDSHIP, WE HAVE LEARNED TO COOK BESHBARMAK»: TYPOLOGICAL MODELS OF INTERETHNIC INTERACTIONS IN SAMARA TRANS-VOLGA REGION}

(C) 2018

Iagafova Ekaterina Andreevna, doctor of historical sciences, professor,

head of Philosophy, History and Theory of World Culture Department

Demidov Alexander Nikolayevich, candidate of philosophical sciences, associate professor of Philosophy, History and Theory of World Culture Department Samara State University of Social Sciences and Education (Samara, Russian Federation)

Abstract. The paper presents the experience of study of interethnic interactions in Samara Trans-Volga region on the example of Belozerki village of Krasnoyarskiy District of the Samara Region. Theoretical and methodological approaches were determined by the concept of «ethnic boundaries», taking into account differential features in the cultural codes of the contacting groups, as well as some other factors (historical, social, demographic, ecological, etc.) that influence the formation of interethnic relations. The purpose of the study was to identify the mechanism of ethnic groups interaction historically living in the village in situations of interethnic contacts (including contacts with migrant communities), factors determining the formation and maintenance of ethno cultural identity of groups and ethnic boundaries between them, to determine the nature of mutual socio-cultural adaptation of groups. During the study the situation of interethnic interaction in the language, socio-economic and ethno-cultural spheres was analyzed taking into account a historical factor; characteristics of ethnic dichotomies (ethnic markers) were given, mainly on the example of predominant groups of the Russians, the Chuvash and the Mordovians. The results of the study showed the presence of «ethnic boundaries», determined by the history of Belozerki settlement, as well as cultural specifics, features of language behavior and ethnic identification, the nature of socio-economic contacts of groups, and determined the change of various models of interethnic interaction during half a century history and their diversity at present. The factors that support the group identity of the Mordovians and the Chuvash are the language, functional in the family and domestic sphere, intra-ethnic contacts in everyday, but more often in festive and ritual spheres. The study is based on archival, published sources and field materials of the authors (2018).

Keywords: interethnic relations; ethnic borders; Samara Trans-Volga region; Russians; Chuvash; Mordovians; ethnic groups; ethnic culture; ethnicity; ethnic identification; isolation; integration; assimilation; migrants; sociocultural adaptation; migration; Belozerki; Samara Region.

УДК 930.02

DOI $10.24411 / 2309-4370-2018-14221$

Статья поступила в редакцию 07.07.2018

\section{ЭЛЕКТРОННЫЙ ДОКУМЕНТ КАК ОБЪЕКТ ДОКУМЕНТОВЕДЕНИЯ: ИСТОРИОГРАФИЧЕСКИЙ ОБЗОР}

(C) 2018

Суровцева Наталия Геннадиевна, кандидат исторических наук,

доцент кафедры автоматизированных систем документационного обеспечения управления

Российский государственный гуманитарный университет (г. Москва, Российская Федераичя)

Аннотащия. Статья посвящена выявлению и анализу основных исследований российских документоведов и специалистов смежных научных дисциплин в области изучения электронных документов с момента появления этого понятия в конце 1990-х годов и до настоящего времени. Автор рассматривает формирование действующего подхода к определению понятия «электронный документ», изучение его особенностей, связанных со спецификой информационной среды и электронного носителя информации, определения основных категорий электронных документов и признаков их классификации. К началу ХХІ века было сформулировано непротиворечивое для документоведения и архивоведения понятие электронного документа, предложено его рабочее определение, при разработке которого ученые исходили из того, что электронный документ в первую очередь является документом, выполняет те же функции, обладает теми же признаками, что и 